\title{
The study of genetic polymorphisms related to serotonin in Alzheimer's disease: a new perspective in a heterogenic disorder
}

J.R.M. Oliveira ${ }^{1,2}$ and M. Zatz ${ }^{2}$

\author{
${ }^{1}$ Laboratório de Imunopatologia Keizo Asami, \\ Universidade Federal de Pernambuco, Recife, PE, Brasil \\ ${ }^{2}$ Centro de Estudos do Genoma Humano, Departamento de Biologia, \\ Instituto de Biociências, Universidade de São Paulo, São Paulo, SP, Brasil
}

\section{Correspondence \\ M. Zatz \\ Departamento de Biologia \\ Instituto de Biociências, USP \\ 05508-900 São Paulo, SP \\ Brasil \\ E-mail: mayazatz@usp.br}

Presented at the XXVII Annual Meeting of the Brazilian Society of Biochemistry and Molecular Biology, Caxambu, MG, Brasil,

May 23-26, 1998.

J.R.M. O liveira received the "Young Talent in Life-Sciences-98" award for this article from the Sociedade Brasileira de Bioquímica e Biologia Molecular and Amersham Pharmacia Biotech.

Research supported by FAPESP, CNPq and PRONEX.

Received December 30, 1998

Accepted January 26, 1999

\section{Abstract}

Genetic and environmental factors have been implicated in the development of Alzheimer's disease (AD), the most common form of dementia in the elderly. Mutations in 3 genes mapped on chromosomes 21,14 and 1 are related to the rare early onset forms of AD while the $\varepsilon 4$ allele of the apolipoprotein E (APOE) gene (on chromosome 19 ) is the major susceptibility locus for the most common late onset AD (LOAD). Serotonin (5-hydroxytryptamine or 5-HT) is a key neurotransmitter implicated in the control of mood, sleep, appetite and a variety of traits and behaviors. Recently, a polymorphism in the transcriptional control region upstream of the 5-HT transporter (5HTT) gene has been studied in several psychiatric diseases and personality traits. It has been demonstrated that the short variant(s) of this 5-HTT gene-linked polymorphic region (5-HTTLPR) is associated with a different transcriptional efficiency of the 5-HTT gene promoter resulting in decreased 5-HTT expression and 5-HT uptake in lymphocytes. An increased frequency of this 5-HTTLPR short variant polymorphism in LOAD was recently reported. In addition, another common polymorphic variation in the $5-\mathrm{HT}_{2 \mathrm{~A}}$ and $5-\mathrm{HT}_{2 \mathrm{C}}$ serotonin receptor genes previously analyzed in schizophrenic patients was associated with auditory and visual hallucinations in AD. These observations suggest that the involvement of the serotonin pathway might provide an explanation for some aspects of the affective symptoms commonly observed in $\mathrm{AD}$ patients. In summary, research on genetic polymorphisms related to $\mathrm{AD}$ and involved in receptors, transporter proteins and the enzymatic machinery of serotonin might enhance our understanding of this devastating neurodegenerative disorder.
Key words

- Alzheimer's disease

- Allelic association

- Serotonin polymorphisms 
Alzheimer's disease (AD), the most common form of dementia in the elderly, is a complex disorder characterized by a progressive deterioration of memory, language and other cognitive functions. In addition to a genetic contribution, environmental factors such as educational level or the occurrence of head injuries have also been implicated in the development of late onset $\mathrm{AD}$ (LOAD; first symptoms after 60/65 years of age) (1).

Mutations in three relatively rare genes, associated with early onset $\mathrm{AD}$ (EOAD; first symptoms before $60 / 65$ years of age) have been reported in the recent years: the amyloid precursor protein gene (APP), the presenilin 1 gene (PS1) and the presenilin 2 gene (PS2), respectively on chromosomes 21, 14 and $1(2-5)$.

A new susceptibility locus for familial LOAD has been also identified on chromosome 12 (6). On the other hand, the $\varepsilon 4$ allele of the apolipoprotein E (APOE) gene, mapped on chromosome 19, has been reported in numerous studies worldwide as a risk factor associated mainly with the LOAD form (7), which was also confirmed in the Brazilian population (8). More recently, some association studies have shown that the allelic variant $(-427 \mathrm{C})$ and the haplotype [-491A-427C] of the APOE promoter are associated with an increased risk for AD $(9,10)$.

Several hypotheses have been proposed to address the biological mechanisms by which APOE affects the relative risk (and age at onset) to develop $\mathrm{AD}$, including the possibility that APOE somehow contributes to deposition of the amyloid $B$ peptide (7).

This year, Leuween et al. (11) found frameshift mutants of $\beta$ amyloid precursor protein and ubiquitin-B in Alzheimer and Down patients and suggested that transcript mutations could be an important factor in non-familial AD.

Serotonin (5-hydroxytryptamine or 5-HT) is a key neurotransmitter in the central and peripheral nervous systems that is implicated in the control of mood, sleep, appetite and a variety of traits and behaviors. Its potential role in psychiatric conditions such as depression, obsessive-compulsive disorder, schizophrenia and $\mathrm{AD}$ has been the subject of considerable study (12). The 5HT transporter (5-HTT) acts by regulating the magnitude and duration of serotoninergic neurotransmission and of the peripheral actions of 5-HT (13). 5-HTT may therefore be involved in the pathogenesis of several psychiatric disorders (14-17). 5-HTT is encoded by a gene at $17 \mathrm{q} 11.1-\mathrm{q} 12$ with 14 exons which spans approximately $35 \mathrm{~kb}$ (1822).

Polymorphism in the transcriptional control region upstream of the 5-HTT gene has been reported. The long and short variants of this 5-HTT gene-linked polymorphic region (5-HTTLPR) have different transcriptional efficiency of the 5-HTT gene promoter resulting in decreased 5-HTT expression and 5-HT uptake in lymphocytes. This polymorphism has been studied in several psychiatric diseases, and personality traits with some contradictory findings (16,17,23-30).

In a European study, Collier et al. (17) found that the frequency of the low-activity short variant(s) of the 5-HTTLPR was higher among patients with affective disorders than in normal controls. However, in a study of 86 unrelated patients ( 47 with bipolar disorder and 39 with schizophrenia) and 98 normal controls from the Brazilian population we observed no statistically significant differences among the three groups (31).

An increased frequency of the 5-HTTLPR short variant polymorphism and LOAD was recently reported by $\mathrm{Li}$ et al. (32) and confirmed by us in a Brazilian sample of $A D$ patients (33). Subsequently we demonstrated that the association of the short variant in the APOE $\varepsilon 4$ allele does not increase the risk for LOAD (34).

On the other hand, common polymorphic variations in the $5-\mathrm{HT}_{2 \mathrm{~A}}$ and $5-\mathrm{HT}_{2 \mathrm{C}}$ seroto- 
nin receptor genes (102-T/C and Cys 23 Ser polymorphism, respectively) have been analyzed in patients with schizophrenia and with different responses to the drug clozapine (35-37).

Another recent study has shown that the $5-\mathrm{HT}_{2 \mathrm{~A}}$ and 5- $\mathrm{HT}_{2 \mathrm{C}}$ serotonin receptor genes were respectively associated with auditory and visual hallucinations in AD. Interestingly, these polymorphisms are clinically silent until the onset of the neurodegenerative process (38).

The mechanisms by which these polymorphisms may alter the action of serotonin on the synaptic gap are not known since the T102C variant does not change the amino acid sequence of this serotonin receptor. According to Arranz et al. (37), the secondary protein structure or the mRNA stability might be altered by this variant although Burnett and Harrison (39) found no relation between the $\mathrm{T} 102 \mathrm{C}$ genotype and receptor abundance. An alternative hypothesis would be that this polymorphism may be in linkage disequilibrium with another causative mutation in close proximity to this marker.

In any case, the involvement of the serotonin pathway might provide an explanation for some aspects of the affective symptoms commonly observed in $\mathrm{AD}$ patients. It is possible that the depressive symptoms associated with $\mathrm{AD}$ might be related to these or other still unknown biological factors rather than representing only the patient reaction to the diagnosis and to the limitations imposed by the disease (40). Relevant to this hypothesis is the fact that the medication currently used to circumvent the mood alterations in AD is supposed to inhibit serotonin uptake.

In summary, research on genetic polymorphisms related to $\mathrm{AD}$ and involved in receptors, transporter proteins and the enzymatic machinery of serotonin might enhance our understanding of the pathological mechanisms involved in this devastating neurodegenerative disorder.

\section{Acknowledgments}

We would like to acknowledge the collaboration of the following persons during the study: Constancia Urbani, Dr. Maria Rita Passos-Bueno and Dr. Mariz Vainzof from Centro de Estudos do Genoma Humano, IB, USP, Dr. Paulo Roberto Brito-Marques, Dr. José Luis de Lima Filho, Dr. Luis Bezerra de Carvalho Junior, Dr. Marcos Morais, Dr. Luis Gustavo Maia, Rodrigo Gallindo and Daniel Rocha from Laboratório de Imunopatologia Keizo Asami, UFPe, Dr. Valentim Gentil, Dr. Homero Vallada, Dr. Valéria Lauriano, Dr. Helio Elkis and Dr. Beny Lafer from Instituto de Psiquiatria, FM, USP.

\section{References}

1. Eastwood R, Amaducci L, Brayne C, Broe T, Bums A, Copeland J , Dickens B, Goate A, Hachinski V, Henderson S, J olles J, Morris J, Ritchie K, Roses A, Rossor M, Schellenberg G, Skoog I, Storandt M, Tallis R, Whitehouse P, Clark S, Evans I, Horton R \& Sharp D (1996). The challenge of the dementias. Lancet, 374: 13031307.

2. Goate $A$, Chartier-Harlin MC, Mullan $M$, Brown J , Crawford F, Fidani L, Ginffra L, Haynes A, Inving N, James L, Mant R, Newton $\mathrm{P}$, Rooke $\mathrm{K}$, Roques $\mathrm{P}$, Talbot $\mathrm{C}$, Pericak-Vance $M$, Roses A, Williamson R, Rossor M, Owen M \& Hardy J (1991).
Segregation of a missense mutation in amyloid precusor protein gene with familial Alzheimer's disease. Nature, 349: 704706.

3. Sherrington R, Rogaev El, Liang $Y$, Rogaeva EA, Levesque G, Ikeda $M$, Chi $H$, Lin C, Li G, Holman K, Tsuda T, Mar L, Foncin J F, Bruni AC, Montesi MP, Sorbis $S$, Rainero I, Pinessi L, Nee L, Chumakov I, Pollen D, Brookses A, Sansean P, Polinsky RJ, Wasco W, da Silva HAR, Haines J L, Pericak-Vance MA, Tanzy RE, Roses AD, Fraser PE, Rommens J M \& St. George-Hyslop PH (1995). Cloning of a gene bearing missense mutations in early- onset familial Alzheimer's disease. Nature, 375: 754-760.

4. Levy-Lahad E, Wijsman EM, Nemens E, Anderson L, Goddard KAB, Weber J L, Bird TD \& Schellenberg GD (1995). A familial Alzheimer's disease locus on chromosome 1. Science, 269: 970-973.

5. Levy-Lahad E, Wasco W, Poorkaj P, Romano DM, Oshima J, Pettigel WH, Yu C, J ondro PD, Schimidt SD, Wang K, Crowley AC, Fu YH, Guenette SY, Galas D, Nemens E, Wijsman EM, Bird TD, Schellenberg GD \& Tanzi RE (1995). Candidate gene for the chromosome 1 familial Alzheimer's disease locus. Science, 
269: 973-977.

6. Pericak-Vance MA, Bass MP, Yamaoka LH, Gaskell PO, Scott WK, Terwedon HÁ, Menold MM, Conneally PM, Small GW, Vance J M, Saunders AM, Roses AD \& Haines J L (1997). Complete genomic screen in late-onset familial Alzheimer disease: Evidence for a new locus on chromosome 12. Journal of the American Medical Association, 278: 1237-1241.

7. Strittmatter WJ, Saunders AM, Schmechel D, Pericak-Vance MA, Enghild J , Salvesen GS \& Roses AD (1993). Apolipoprotein E: High avidity binding to ßamyloid and increased frequency of type 4 allele in late-onset familial Alzheimer's disease. Proceedings of the National Academy of Sciences, USA, 190: 19771981.

8. Oliveira J RM, Shimokomaki CM, BritoMarques PR, Okuma M, Passos-Bueno MR, Zatz M \& Lima-Filho JL (1997). The use of apolipoprotein $E$ genotype for preclinical detection of Risk's group for Alzheimer's disease. American J ournal of Medical Genetics (Neuropsychiatric Genetics), 74: 216-217.

9. Artiga MJ, Bullido MJ, Frank A, Sastre I, Recuero M, Garcia MA, Lendon CL, Han SW, Momis J C, Vásquez J, Goate A \& Valdivieso F (1998). Risk for Alzheimer's disease correlates with transcriptional activity of the APOE gene. Human Molecular Genetics, 7: 1887-1892.

10. Lambert JC, Berr C, Pasquier F, Delacourte A, Frigard B, Cottel D, PérezTu J, Mouroux V, Mohr M, Cécyre D, Galasko D, Lendon C, Poirier J, Hardy J, Mann D, Amouyel P \& Chartier-Harlin MC (1998). Pronounced impact of Th1/E47cs mutation compared with -491 AT mutation on neural APOE expression and risk of developing Alzheimer's disease. Human Molecular Genetics, 7: 1511-1516.

11. Leuween FWV, Kleijn DPV, van den Hurk $\mathrm{HH}$, Neubauer A, Sonnemans MAF, Sluijs JÁ, Köycü S, Ramdjielal RDJ, Salehi A, Martens GJ M, Grosveld FG, Burbach PH $\&$ Hol EM (1998). Frameshift mutants of $B$ amyloid precussor protein and ubiquitin-B in Alzheimer's and Down patients. Science, 279: 242-247.

12. Meltzer $H$, Arora $R$, Baber $R \&$ Tricou $B$ (1981). Serotonin uptake in blood platelets of psychiatric patients. Archives of General Psychiatry, 38: 1322-1329.

13. Risch SC \& Nemeroff CB (1981). Neurochemical alterations of serotoninergic neuronal systems in depression. J oumal of Clinical Psychiatry, 38: 1322-1329.

14. Sthal S, Woo D, Mefford I, Berger P \&
Ciaranello R (1983). Hyperserotonemia and platelet serotonin uptake in schizophrenia and affective disorders. American J oumal of Psychiatry, 140: 26-31.

15. J oyce J N, Shame A, Lexow N, Winokur A, Casanova MF \& Kleinman J E (1993). Serotonin uptake sites and serotonin receptors are altered in the limbic system of schizophrenics. Neuropsychopharmacology, 8: 315-336.

16. Lesch KP, Bengel $D$, Heils A, Sabol SZ, Greenberg BD, Petri S, Benjamin J , Muller CR, Hamer DH \& Murphy DL (1996). Association of anxiety-related traits with a polymorphism in the serotonin transporter gene regulatory region. Science, 274: 1527-1531.

17. Collier DA, Stober G, Li T, Heils A, Catalano M, Di Bella D, Arranz MJ , Murray RM, Vallada HP, Bengel D, Muller CR, Roberts GW, Smeraldi E, Kirov G, Sham P \& Lesch KP (1996). A novel functional polymorphism within the promoter of the serotonin transporter gene: possible role in susceptibility to affective disorders. Molecular Psychiatry, 1: 453-460.

18. Lesch KP, Wolozin BL, Estler HC, Murphy $D L \&$ Riederer P (1993). Isolation of a cDNA encoding the human brain serotonin transporter. J oumal of Neural Transmission, 91: 67-73.

19. Lesch KP, Balling U, Gross J Strauss K, Murphy DL \& Riederer P (1994). Organization of the human serotonin transporter gene. J ournal of Neural Transmission (Genetic Section), 95: 157-162.

20. Ramamoorthy S, Bauman A, Moore K, Han H, Yang-Feng L, Chang A, Ganapathy V \& Blakely R (1993). Regulation of the human serotonin transporter: Antidepressant and cocaine sensitive human serotonin transporter: molecular cloning, expression and chromosomal localization. Proceedings of the National Academy of Sciences, USA, 90: 2542-2546.

21. Gelernter J, Pakstis AJ \& Kidd KK (1995). Linkage mapping of the serotonin transporter protein gene SCL 6 A4 on chromosome 17. Human Genetics, 96: 677-680.

22. Heils A, Teufel A, Petri S, Stober G, Riederer P, Bengel D \& Lesch KP (1996). Allelic variation of human serotonin transporter gene expression. J ournal of Neurochemistry, 66: 2621-2626.

23. Kunugi $H$, Tatsumi $M$, Sakai $T$, Hattori $M$ \& Nanko S (1996). Serotonin transporter gene polymorphism and affective disorder. Lancet, 347: 1340 (Abstract).

24. Ebstein RP, Gritsenko I, Nemanov L, Frisch A, Osher Y \& Belmaker RH (1997). No association between the serotonin transporter gene regulatory region polymorphism and the three dimensional personality questionnaire (TPQ) temperamental of harm avoidance. Molecular Psychiatry, 2: 224-226.

25. Klauck SM, Poustka F, Benner A, Lesch KP \& Poustka A (1997). Serotonin transporter (5-HTT) gene variants associated with autism? Human Molecular Genetics, 6: 2233-2238.

26. Deckert J, Catalano M, Heils A, Di Bella D, Friess $F$, Politi E, Franke $P$, Nothen MM, Maier W, Bellodi L \& Lesch KP (1997). Functional promoter polymorphism of the human serotonin transporter: Lack of association with panic disorder. Psychiatric Genetics, 7: 45-47.

27. Billet EA, Richter MA, King N, Heils A, Lesch KP \& Kennedy J L (1997). Obsessive compulsive disorder, response to serotonin reuptake inhibitors and the serotonin transporter gene. Molecular Psychiatry, 2: 403-406.

28. Hoehe MR, Wendel B, Grunewald I, Chiaroni P, Levy N, Morris-Rosendahl D, Macher J P, Sander T \& Crocq MA (1998). Serotonin transporter (5-HTT) gene polymorphisms are not associated with susceptibility to mood disorders. American J ournal of Medical Genetics (Neuropsychiatric Genetics), 81: 1-3.

29. Esterling LE, Yoshikawa T, Turner G, Badner J Á, Bengel D, Gershon ES, Berrettini WH \& Detera-Wadleigh SD (1998). Serotonin transporter (5-HTT) gene and bipolar affective disorder. American J ournal of Medical Genetics (Neuropsychiatric Genetics), 81: 37-40.

30. Furlong RA, Ho L, Walsh $C$, Rubinsztein J S, J ain S, Paykel ES, Easton DF \& Rubinsztein DC (1998). Analysis and metaanalysis of two serotonin transporter gene polymorphisms in bipolar and unipolar affective disorders. American J ournal of Medical Genetics (Neuropsychiatric Genetics), 81: 58-63.

31. Oliveira J RM, Otto PA, Vallada HP, Lauriano V, Elkis $H$, Lafer $B$, Vasques $L$, Gentil V, Passos-Bueno MR \& Zatz M (1998). Analysis of a novel functional polymorphism within the promoter region of the serotonin transporter gene (5-HTT) in Brazilian patients affected by bipolar disorder and schizophrenia. American J ournal of Medical Genetics (Neuropsychiatric Genetics), 81: 225-227.

32. Li T, Holmes C, Sham PC, Vallada HP, Birkett J, Kirov G, Lesch KP, Powell J, Lovestone S \& Collier D (1997). Allelic functional variation of serotonin transporter expression is a susceptibility factor 
for late onset Alzheimer's disease. NeuroReport, 8: 683-686.

33. Oliveira J RM, Gallindo RM, Maia LGS, Brito-Marques PR, Otto PA, PassosBueno MR, Morais J $r$ MA \& Zatz M (1998). The short variant of the polymorphism within the promoter region of the serotonin transporter gene is a risk factor for late onset Alzheimer's disease. Molecular Psychiatry, 3: 438-441.

34. Oliveira J RM, Shimokomaki CM, BritoMarques PR, Gallindo RM, Okuma M, Maia LGS, Otto PA, Passos-Bueno MR \& Zatz M (1999). The association of the short variant of the 5-HTTLPR polymorphism and the apoE $\varepsilon 4$ allele does not increase the risk for late onset
Alzheimer's disease. Molecular Psychiatry, 4: 19-20.

35. Williams J, McGuffin $P$, Nöthen $M$, Owen MJ \& the EMASS Consortium (1997). Meta-analysis of association between the 5-HT receptor T102C polymorphism and schizophrenia. Lancet, 349: 1221.

36. Williams J, Spurlock G, McGuffin P, Mallet J, Nöthen MM, Gill M, Aschauer $H$, Nylander PO, Macciardi F, Owen MJ \& EMASS group (1996). Association between schizophrenia and T102C polymorphism of the 5-hydroxytryptamine type $2^{\mathrm{a}}$-receptor gene. Lancet, 347: 12941296.

37. Arranz $M$, Collier $D$, Sodhi $M$, Ball $D$, Roberts G, Price J , Sham P \& Kerwin R (1995).
An association between clozapine response and allelic variation in $5-\mathrm{HT}_{2 \mathrm{~A}}$ receptor genes. Lancet, 346: 281-282.

38. Holmes C, Arranz MJ, Powell AF, Collier DA \& Lovestone S (1998). 5-HT2A and 5HT2C receptor polymorphisms and psychopathology in late onset Alzheimer's disease. Human Molecular Genetics, 7: 1507-1509.

39. Bumett PWJ \& Harrison PJ (1995). Genetic variation of the $5-\mathrm{HT}_{2 \mathrm{~A}}$ receptor and response to clozapine. Lancet, 346: 909.

40. Feinberg $T \& \&$ Goodman B (1984). Affective illness, dementia and pseudodementia. J ournal of Clinical Psychiatry, 3: 99103. 